\title{
Cause and Effect in Ioane Petritsi's Commentary on Proclus' Elements of Theology
}

\author{
Lela Alexidze \\ Tbilisi Ivane Javakhishvili State University, Georgia
}

\section{$1 \quad$ Introduction}

The aim of this paper is to analyse certain aspects of the problem of causality, focusing our attention on the cause and effect relationship as it is exposed and interpreted by Ioane Petritsi in his Commentary on Proclus' Elements of Theology. ${ }^{1}$

Petritsi's Commentary on Proclus' Elements is the first detailed explanation of this text in the western and eastern European Christian milieu. Written in Georgian in the 12th century, it is preceded by Petritsi's translation of the whole text of the Elements. ${ }^{2}$ Compared to the critical approach (Refutatio) to the same text by a Byzantine scholar of the 12th century, Nicholas, bishop of Methone, Petritsi's Commentary is an amazingly positive interpretation of Proclus' work. ${ }^{3}$ Petritsi holds in high esteem not only Proclus' Elements but all his philosophy and, together with it, the whole Platonic tradition. In my opinion, in principle, Petritsi's Commentary was not written from the Christian position, although this would have been typical for a Georgian intellectual of his epoch, including those scholars who were, like Petritsi, educated in the Byzantine milieu. In his Commentary, Petritsi did not interpret Proclus' philosophy as a theory lacking its own intrinsic value, or as a text, which could be, first and foremost, only a preparation, an introduction or an organon for Christian theology. Instead, Proclus' philosophy was valuable for Petritsi, on the one hand, in itself, and, on the other, it was supposed to serve, in his opinion, as a start and an endpoint, and also as a method, that could be used in mathematics, logic, physics, and theology. 4

1 For Petritsi's Commentary see Ioanne Petritsi, Opera, v. II (further quoted with indication of a page and a number of a chapter, or of the prologue or epilogue).

2 For Petritsi's translation of Proclus' Elements see Ioanne Petritsi, Opera, v. I.

3 Alexidze 2014b, p. 239-241.

4 Alexidze 2014b, p. 237.

(C) KONINKLIJKE BRILL NV, LEIDEN, THE NETHERLANDS, 2022 | DOI:10.1163/9789004501331_009 
This is the reason why, I think, we have theses and axioms typical of ancient Neoplatonism in Petritsi's Commentary, although some of them may contradict the basic postulates of Christian theology. In this paper, in the context of the problem of causality, we discuss three themes of Petritsi's Commentary which reveal, to a certain extent, the primarily Neoplatonic character of Petritsi's philosophy and, in some cases, his attempt to 'harmonize' Proclus' theory of the cause and effect relationship with the basic axioms of Christian theology, such as the equality between the first and the second hypostases of the Trinity, and the concept of God as the creator of the material world.

The first issue is quite an 'eclectic' one as far as the general principles of causation are concerned. They are formulated by Petritsi in a typical, traditionally Neoplatonic way as follows: The first cause of everything is the transcendent 'pure' One which is one and nothing else; a cause is always more than its effect; the 'higher' a cause, the further its power is extended; the order of causation can neither be cyclic nor endless, etc.

The second issue concerns the problem of matter's causation. In Petritsi's theory, matter is caused by the supreme One. Matter is neither a product of God's creative power, nor is it the co-existent entity to the demiurge's creative activity (unlike Plato's Timaeus). Instead, in Petritsi's Commentary matter is the lowest level of the production (procession) of beings from the supreme One, representing the level of total formlessness and non-being, similar to Proclus' position. While discussing this theme, our main question will be: in what sense is the supreme One the cause of prime matter?

The third issue embraces the paradox of the first principle, i.e. of the supreme One which is on the one hand transcendent, but, on the other, the cause of everything. Our question will be: in Petritsi's interpretation are these two aspects of the supreme One compatible with each other or not?

While discussing these issues, we shall focus our attention also on other aspects of the problem of causality as far as they are related to the three abovementioned themes.

\section{General Principles of Causality}

According to Petritsi, the first cause of everything is the transcendent 'pure' One which is one and nothing else. ${ }^{5}$ Like Proclus, he thinks that a cause is always more than its effect, and the 'higher' the cause is, the further its power is extended. ${ }^{6}$

5 Ioanne Petritsi, Opera, v. II, p. 3, prologue.

6 Ioanne Petritsi, Opera, v. II, p. 13, ch. 1. 
These are well-known Neoplatonic axioms, firmly shared by Petritsi. However, viewed from the Christian theological perspective, we can conclude that these axioms make it almost impossible (at least from a logical and theoretical point of view) in Petritsi's philosophy for the Son (Logos) to be equal to the Father if he is in any sense caused by Him. Moreover, because of the absolutely pure oneness of the first principle, any kind of plurality, including that of the Trinity, should be excluded. However, there are some indications in the text which allow us to think that Petritsi, in spite of his ancient-Neoplatonic philosophical position (here I mean, first and foremost, two major theses: the absolute supremacy of the One as one; and also the axiom of the supremacy of a cause in relation to its effect), as a Christian philosopher, was sufficiently orthodox as far as he accepted the dogma of equality of the Father and the SonLogos. ${ }^{7}$ Moreover, in his so-called Epilogue he tried to show that Trinity and the One are the same. ${ }^{8}$

As for the purely philosophical conclusions which can be made on the basis of Petritsi's Commentary in the context of the axiom "the cause is more than the effect", here we can say the following: for Petritsi, the hierarchical order of causation is very important not only as an ontological basis for understanding the universal order but also from the epistemological point of view. Thus, he criticizes the followers of Aristotle for transposing the methods applicable to physics to the metaphysical sphere. ${ }^{9}$ The universal order should not be brought into disorder, Petritsi thought, ${ }^{10}$ nor should the last member of the chain of the ontological hierarchy become the first or the order of beings be endless. Moreover, the chain of causes must not be cyclical." ${ }^{11}$ Thus, in Petritsi's opinion, there is a first cause of everything which is causeless. ${ }^{12}$ Therefore, Petritsi thinks we should not confuse the study of effects with that of causes, and we should not suppose that corporeal beings are causes of those entities, the real causes of which are incorporeal beings. The Stoics and Peripatetics, as Petritsi thinks, used to make such mistakes. ${ }^{13}$

As for the axiom "the 'higher' the cause, the further its power is extended", the result of this thesis is the following statement: prime matter depends only on

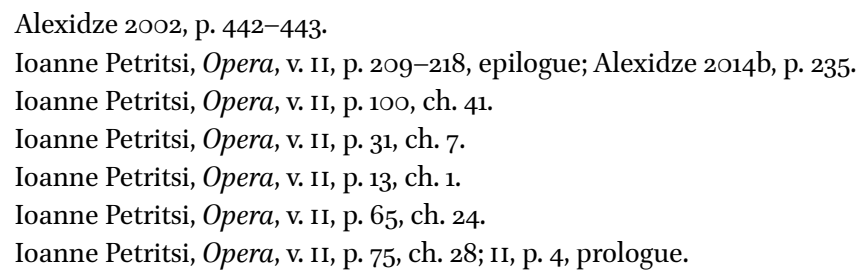


the supreme One, all beings depend on the Intellect (because they have forms), while animated beings depend on the Soul. ${ }^{14}$ We shall come back to this thesis in the next section of our paper.

In order to show the philosophical context in which the problems of causality are discussed by Petritsi, I shall first briefly mention the main philosophical topics related to this issue. These are: (1) cause and effect in the context of

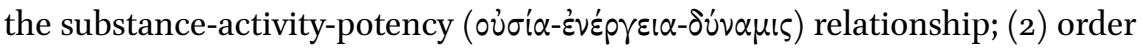
in the hierarchy of the cause-effect relationship, and the mechanism of participation; (3) a cause considered in its effect and an effect considered in its cause; three forms of 'existence' of effects; (4) positive aspect of the affects in the effects; (5) $\dot{\varepsilon} \pi \iota \tau$ เ $о \varphi \eta$ : an effect returns to itself, that is, to its cause; love in the context of the relationship between an effect and its cause; (6) identity, similarity and difference in the cause-effect relationship; the productivity of a cause; (7) cause of a simple existence and causes of particular characteristics of beings.

Now, on the basis of Petritsi's Commentary, we shall discuss these issues more in detail.

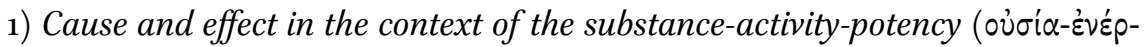
$\gamma \varepsilon 1 \alpha-\delta \dot{v} \alpha \mu(\varsigma)$ relationship. According to Petritsi, the transcendent One is above every kind of potency and activity, and above creativity, because potency and activity are related to nature, but the One is free from all types of nature. ${ }^{15}$ Every kinds of potency and activity is like the substance: as Petritsi says, if the substance is intellectual, then the potency and activity are also intellectual. ${ }^{16}$ The potency and activity are generally 'worse' than the substance, ${ }^{17}$ though they all (i.e. potency, activity, and substance) are the same in the Intellect, ${ }^{18}$ while the One, as Petritsi says, is superior to activity, potency and substance. ${ }^{19}$ As for the soul, its substance is not temporal, although its activity is. ${ }^{20}$

2) Order in the hierarchy of the cause-effect relationship, and the mechanism of participation. As Petritsi says, every lower being participates in the higher one by means of intermediate causes. Thus, all bodies and embodied beings

\footnotetext{
14 Ioanne Petritsi, Opera, v. II, p. 189, ch. 174; II, p. 58-59, ch. 2.

15 Ioanne Petritsi, Opera, v. II, p. 18, ch. 1.

16 Ioanne Petritsi, Opera, v. II, p. 31, ch. 7 .

17 Ioanne Petritsi, Opera, v. II, p. 151, ch. 105.

18 Ioanne Petritsi, Opera, v. II, p. 9, prologue.

19 Ioanne Petritsi, Opera, v. II, p. 17-18, ch. 1.

$20 \quad$ Ioanne Petritsi, Opera, v. II, p. 203-204, ch. 206.
} 
participate in the intellectual and unmovable substance by means of the Soul, while the Soul (as Hypostasis) participates in the realm of the true Being and the Henads by means of the Intellect, ${ }^{21}$ and both the Soul and the Intellect participate in the 'sun of the Henads' by means of the true Being. ${ }^{22}$ An individual soul participates in the Intellect by means of an individual intellect and the cosmic soul. However, a soul which is sometimes non-intellectual cannot participate in the cosmic soul without a mediator, ${ }^{23}$ while the universal soul is always firmly established in the Intellect. ${ }^{24}$ In Petritsi's opinion, no immediate participation in a being which is more than one level higher is possible. Thus, though everything, as Petritsi believes, strives towards the Good, it can be reached only by means of the intermediate causes. ${ }^{25}$ The more intermediate causes there are, the more the effect is distanced from the cause and unlike it. $^{26}$

3) A cause considered in its effect and an effect considered in its cause; three forms of 'existence' of effects. As Petritsi says, though the potencies and the 'self' of the Henads and gods can be considered in the effects, they are by themselves transcendent. ${ }^{27}$ Like Proclus, Petritsi analyses three forms of 'existence' of an effect: in its cause, according to its own existence, and by participation. Interestingly, he not only translates these concepts into Georgian, but expresses them also in a Greek form, in Georgian transliteration: kat'aitian, kat' hyparxin, kata methexin. $^{28}$

4) Positive aspect of the affects in the effects. In Petritsi's opinion, some affects are good for the effects. Thus, to become one (unified) is good for them. ${ }^{29}$ As Petritsi says, unified beings need the One by means of which they become one, while the supreme One does not become one. ${ }^{30}$ Some affects are good for the effects; thus, to become one (unified) is good for them. ${ }^{31}$ Therefore, unification is regarded by Petritsi as a positive affect for the effects.

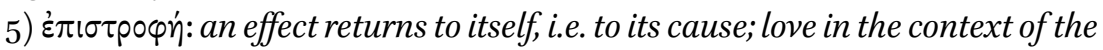
relationship between an effect and the cause. According to Petritsi, the supreme

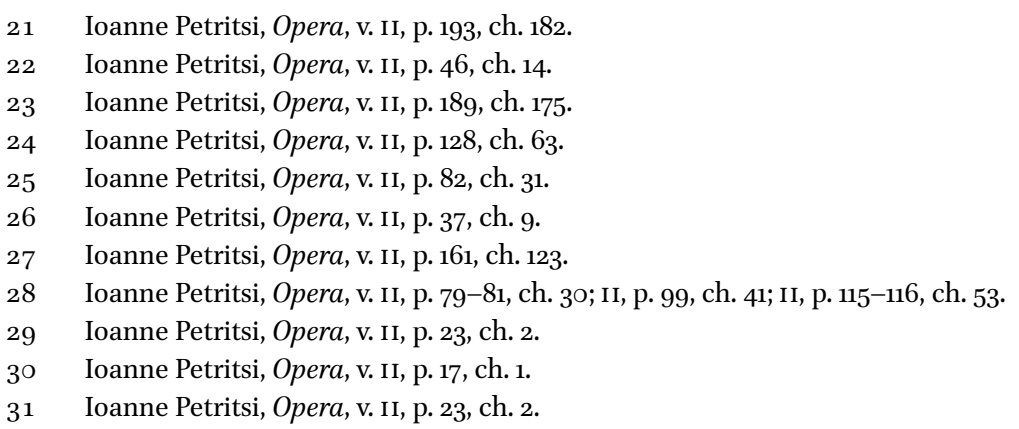


Goodness is the One and it is the first cause of the existence of beings. Correspondingly, everything strives back to the Goodness / the supreme One as to their cause. ${ }^{32}$ All effects must get something from their causes in order to be able to return to them. They become their unity from the transcendent One. This is the basis of their reversion. ${ }^{33}$ As Petritsi explains, the love and the desire of a being for its own form is the love and the desire for its own one, and this is also the love and the desire for the supreme One. ${ }^{34}$ According to Petritsi, an incorporeal being participates first in the one in itself, then through it in the supreme Henads, and through them, it is related to the supreme One. ${ }^{35}$ Through the one in itself a soul strives toward the transcendent One. ${ }^{36}$ As Petritsi explains, an individual mind participates in the supreme One through the one in itself, on the one hand, and through the universal Intellect, on the other. ${ }^{37}$ The Soul and the Intellect participate in the One through the Henads. ${ }^{38}$ According to Petritsi, through the one within us we connect to the supreme One, abandoning the multiplicity of forms and even our own essence. ${ }^{39}$ The cosmos strives for the true Being and to its Father-the One..$^{40}$ As Petritsi says, even matter loves the transcendent principle, and that is why there are traces of the forms in formless matter, because it too desires beauty. ${ }^{41}$ Thus, everything strives to the substantial principle in itself, i.e. to its own one, and this does not happen, as Petritsi says, by chance, because a being cannot love something which is alien and other for it. This means that an effect desires and loves its cause and its own self, striving back to the cause which is essentially its own principle and not something exterior to it. ${ }^{42}$ According to Petritsi, the light of the one is sown in all beings; the light means not something external but an inner eye, a seed and a cause. ${ }^{43}$ Therefore, all causes are the objects of desire for the effects, because the last ones are produced by them, and they love their causes and strive back toward them. ${ }^{44}$

32 Ioanne Petritsi, Opera, v. II, p. 43-44, ch. 12.

33 Ioanne Petritsi, Opera, v. II, p. 75, ch. 28.

34 Ioanne Petritsi, Opera, v. II, p. 92, ch. 39.

35 Ioanne Petritsi, Opera, v. II, p. 101, ch. 42; p. 102, ch. 43.

36 Ioanne Petritsi, Opera, v. II, p. 111, ch. 51 .

37 Ioanne Petritsi, Opera, v. II, p. 153, ch. 109.

38 Ioanne Petritsi, Opera, v. II, p. 47, ch. 14.

39 Ioanne Petritsi, Opera, v. II, p. 48, ch. 15.

40 Ioanne Petritsi, Opera, v. II, p. 128-129, ch. 63.

41 Ioanne Petritsi, Opera, v. II, p. 75, ch. 28.

42 Ioanne Petritsi, Opera, v. II, p. 88, ch. 35 .

43 Ioanne Petritsi, Opera, v. II, p. 48, ch. 15.

44 Ioanne Petritsi, Opera, v. II, p. 36, ch. 9. 
The mode of the reversion of effects toward their causes depends on the substance of each being. If it is only a being - neither a living being nor a rational substance - then it loves its cause and strives toward it only as a being; if it has a potency for life, then it loves its cause by means of its substance which is a living being. ${ }^{45}$ As Petritsi says, all beings have their own form and each being desires its own form. ${ }^{46}$ According to Petritsi, similarity is the reason for both the production and the reversion of beings to their principles. ${ }^{47}$ Love is the basis of the reversion, ${ }^{48}$ but love is possible, as Petritsi says, only if there is a similarity between a lover and the object of its love, because a being does not love something which is not similar to it. ${ }^{49}$ However, a body cannot return to itself and its causes, ${ }^{50}$ because it is distributed in the parts, and parts are in different places, even if a body has a form of a sphere. Thus, according to Petritsi, only a non-corporeal being is able to accomplish a complete reversion to itself. ${ }^{51}$ Consequently, everything that is able to return to itself and its causes is non-corporeal. A non-corporeal being goes back to itself also when it is in a bodily condition, but not as perfectly as when it is without a body. ${ }^{52}$ According to Petritsi, a non-corporeal being, while participating in its causes, participates in its own one i.e. in its own 'center', and then, through the one in itself, which it views as a god and as a seed of the supreme One, it participates in the highest Henads, ascending even to the highest One. ${ }^{53}$ Petritsi, like Proclus, thinks that a human soul descends completely into the material realm and no part of it remains in the intelligible world; that is a reason why, as he thinks, no perfect union is possible for a human being as long as it is 'connected' with a body, though we can, by means of the intellectual way of life and concentration on the 'one within us' be free from the bodily bounds and approach the Intellect. ${ }^{54}$ Our soul in a corporeal condition is, Petritsi says, like Adam, who is deprived of the intellect, that is why it received the body as a cloth. Thus, according to Petritsi, a soul is dressed in leather chitons, i.e. in a body, because of its non-intellectuality. However, a soul drops these corporeal clothes when

45 Ioanne Petritsi, Opera, v. II, p. 32, ch. 39; II, p. 92, ch. 39.

$46 \quad$ Ioanne Petritsi, Opera, v. II, p. 92, ch. 39.

47 Ioanne Petritsi, Opera, v. II, p. 78, ch. 29.

48 Ioanne Petritsi, Opera, v. II, p. 83, ch. 31.

49 Ioanne Petritsi, Opera, v. II, p. 83, ch. 32; II, p. 86, ch. 34.

$50 \quad$ Ioanne Petritsi, Opera, v. II, p. 48, ch. 15; II, p. 49, ch. 49.

$5^{1}$ Ioanne Petritsi, Opera, v. II, p. 105, ch. II, 49; p. 101, ch. 42.

$5^{2}$ Ioanne Petritsi, Opera, v. II, p. 50, ch. 16.

53 Ioanne Petritsi, Opera, v. II, p. 101, ch. 42; II, p. 102, ch. 43.

54 Alexidze 2014a, p. 189-191. 
it starts purifying itself, and rises back to its father and cause.$^{55}$ As Petritsi says, an intellectual soul knows itself, ${ }^{56}$ and the knowledge of self means the knowledge of the causes. ${ }^{57}$

6) Identity, similarity and difference in the relationship between a cause and its effect; the productivity of a cause. According to Petritsi, the cause of one series is not a cause of another, ${ }^{58}$ and the properties of the principles of one series are not the properties of another. ${ }^{59}$ There is a similarity as well as a difference between a cause and its effect. As Petritsi says, in non-corporeal beings there is more similarity, whereas in corporeal beings there is more difference. That is why non-corporeal beings are better images of the One than corporeal beings. ${ }^{60}$ However, according to Petritsi, though the effect is mainly similar to its cause, the 'interference' of matter can make the similarity less clear. ${ }^{61}$ As Petritsi says, a cause produces its effect from its own identity; from itself as a paradigm it produces the effect as its second self and as its image. ${ }^{62} \mathrm{~A}$ cause and its effect are not completely distanced from each other, because, as Petritsi explains, if they were, there would not be any relationship between them. On the other hand, if a cause and its effect were completely identical to each other, neither any kind of production and harmony among beings, nor any kind of distinction between them would be possible. Thus, as Petritsi sums up, a cause and its effect are similar to each other and also distinct from each other. ${ }^{63} \mathrm{An}$ effect must be in the cause, then it must proceed and become different from the cause. ${ }^{64}$ As Petritsi says, an effect has its principle in the cause not as in something other but as in its own self. Thus, an effect remains in the cause, but it is not completely similar to it. ${ }^{65}$ The productive nature produces first likeness and then unlikeness. ${ }^{66}$ In Petritsi's opinion, that which preserves its own identity is the cause of the production of another being. ${ }^{67}$ This is the reason, as Petritsi

Ioanne Petritsi, Opera, v. II, p. 205, ch. 209; II, p. 205, ch. 210; II, 206, ch. 211. Gigineishvili 2007, p. 195-205.

56 Ioanne Petritsi, Opera, v. II, p. 200, ch. 197.

57 Ioanne Petritsi, Opera, v. II, p. 185, ch. 167.

58 Ioanne Petritsi, Opera, v. II, p. 95, ch. 40.

59 Ioanne Petritsi, Opera, v. II, p. 10, ch. 42.

6o Ioanne Petritsi, Opera, v. II, p. 79, ch. 29.

61 Ioanne Petritsi, Opera, v. II, p. 88, ch. 35 .

62 Ioanne Petritsi, Opera, v. II, p. 71, ch. 26.

63 Ioanne Petritsi, Opera, v. II, p. 75, ch. 28.

64 Ioanne Petritsi, Opera, v. II, p. 88, ch. 35 .

65 Ioanne Petritsi, Opera, v. II, p. 8o, ch. 3 .

66 Ioanne Petritsi, Opera, v. II, p. 156, ch. 113.

67 Ioanne Petritsi, Opera, v. II, p. 78-79, ch. 29. 
says, why a cause produces an effect. Only those beings that produce others can be compared with the first One which is the producer of everything. Therefore, a being which remains only in itself and keeps its own self without sharing it with other beings, i.e. without producing effects, cannot serve as a cause for other beings. ${ }^{68}$ Thus, beings which are not productive are unlike the transcendent supreme cause. ${ }^{69}$ If a principle cannot produce, it is unproductive; if it is unproductive, it is not similar to the first One that produces everything. ${ }^{70}$ As Petritsi says, a complete being, as far as it is complete, immediately produces its effects, imitating the supreme One. Nothing that is not productive is complete, and that is why it is not similar to the supreme principle. The more a cause can diffuse its power, the more it is like the transcendent principle. ${ }^{71}$

7) Cause of a simple existence and causes of particular characteristics of beings. Like Proclus, Petritsi acknowledges the existence of the hierarchical order throughout the whole universe, from the transcendent One down to formless matter. He does not think that there is any other cause of anything except the One / God / Goodness. Consequently, evil has no substance, and matter is not evil by itself, though of course, in Petritsi's opinion, those beings are better that are less inclined toward the corporeal world and matter. ${ }^{72}$ The light of the One is in all beings. As Petritsi says, this is not an accidental light but the inner eye. The one is like a seed in beings and then it makes the form around itself. It is an immoveable cause. The ones on the different levels vary according to their disposition: those closer to the supreme One have priority. ${ }^{73}$ According to Petritsi, the supreme Goodness is the one and the first cause of the existence of the beings. ${ }^{74}$ All beings receive their simple existence from the

68 Ioanne Petritsi, Opera, v. II, p. 63-64, ch. 22.

69 Petritsi explains the reason for the creation of living beings as described in Timaeus in this way: "〈life has been created so 〉 that the fertile and productive image of the One does not remain inactive" (Ioanne Petritsi, Opera, v. II, p. 93, ch. 39; Ioane Petrisi, Kommentar zur Elementatio theologica des Proklos, p. 195; Alexidze 2014b, p. 236). In Petritsi's opinion, everything what is unproductive, is not active, and what is not active, is unlike the transcendent active cause. Thus, the monads of the series must be productive and creative; otherwise there would not be any effects and differences in the series (Ioanne Petritsi, Opera, v. II, p. 6o, ch. 21).

70 Ioanne Petritsi, Opera, v. II, p. 64, ch. 23.

71 Ioanne Petritsi, Opera, v. II, p. 68, ch. 25 .

72 For human being, to be reasonable means, in Petritsi's opinion, to make soul free from corporeal influences and to get closer to its 'father'-intellect. Ioanne Petritsi, Opera, v. II, p. 203-206, ch. 206-211.

73 Ioanne Petritsi, Opera, v. II, p. 48, ch. 15 .

74 Ioanne Petritsi, Opera, v. II, p. 43-44, ch. 12. 
supreme One. ${ }^{75}$ As for the particular characteristics and their qualities, they get them from the particular Henads. ${ }^{76}$

\section{$3 \quad$ Causality and Matter}

According to Petritsi's interpretation, matter is caused by the supreme One. While reading his Commentary, we can conclude that in Petritsi's opinion, matter is neither a product of the creative power of God (or the demiurge), nor is it the co-existent entity to his creative activity. Matter is in Petritsi's Commentary rather the lowest level of the production (procession) of beings from the supreme One, representing the level where total formlessness and non-being is reached. In Petritsi's Commentary, prime matter is, like the supreme One, imperceptible. Matter is a 'non-being', the substrate and privation ( $\sigma \tau \varepsilon \dot{p} p \sigma \iota \varsigma)$ of forms. In the Commentary, the concept of prime matter (matter without any form) is different from the concept of a matter of those beings that possess a form, or are embodied.

In spite of matter's indefiniteness, lack of clarity and ineffableness, as Petritsi understands it, one thing is evident: everything, including matter, depends on the supreme One, ${ }^{77}$ though this does not mean for Petritsi that God is its creator or creator out of nothing. ${ }^{78}$ Matter does not depend, for example, on the Intellect or the Soul, ${ }^{79}$ because, according to Petritsi, "the activity of the Intel-

75 In some cases, Petritsi distinguishes two meanings of 'to be': one meaning includes a formal being (to be something), another one means just simple existence. Petritsi uses two different Georgian words for these two meanings. See Ioane Petrizi 2009, p. 80.

76 Ioanne Petritsi, Opera, v. II, p. 170, ch. 138.

77 Ioanne Petritsi, Opera, v. II, p. 14, ch. 1. Petritsi, unlike Plotinus and Iamblichus, shared Proclus' theory that the power of the One reaches matter. See Proclus, The Elements of Theology, p. 69, 24-29, prop. 72. Here Proclus explains, "why matter, taking its origin from the One, is in itself devoid of Form": the first cause (in this case, the One) is more efficient than the consequent one (in this case, the Intellect). Its activity is not exhausted in the effects and extends further than that of its consequent. See the note of Dodds on prop. 57 in Proclus, The Elements of Theology, p. 231. Cf. Proclus, In Timaeum, I, p. 209, 20 Diehl; Proclus, Théologie platonicienne II, p. 92-93; III, p. 122 Saffrey, Westerink. On Petritsi's theory of matter see Alexidze 2017a, p. 123-134.

78 In my opinion, Petritsi does not share the theory of creation from nothing (neither the supreme One nor the demiurge / Intellect is the creator of matter), and he, like Aristotle and Proclus, believes that the world (cosmos) is eternal (Ioanne Petritsi, Opera, v. II, p. 45, ch. 13; Alexidze 2014b, p. 232).

In Petritsi's opinion, only the power of the One reaches even matter, other causes can- 
lect can reach only those beings, which have form. As for $\sigma \tau \dot{\varepsilon} p \eta \sigma \iota \varsigma$, which means 'privations', this word [...] means that a form has a lack of any other form." 80

Petritsi interprets the dependence of matter on the supreme One in the context of the uniqueness of the first principle: like Proclus, he thinks that the supreme principle is the One and it is one (unique). ${ }^{81}$ Matter is the lowest level in the hierarchy of proceeding from the One. It has no form or figure, is not different in itself and, therefore, has no plurality. In fact, the absence of any specific form and the lack of plurality are the reasons why matter and the One have something in common. This makes evident the sense in which the One is the cause of prime matter. It explains also why matter strives toward the love of the One. ${ }^{82}$ However, there is a substantial difference between the oneness of the supreme One as the cause and the oneness of matter as its effect: the supreme One is 'above' all kinds of composed beings (superior to them), while matter, which is also one, but of another kind, is 'lower' and 'worse' than all other beings and composed entities. ${ }^{83}$ According to Petritsi, matter can be, like

not do it. The power of the Intellect reaches only those beings which have form (Ioanne Petritsi, Opera, v. II, p. 189, ch. 174), and the power of the Soul can spread its activity only as far as animated beings. Intellect cannot grasp entities which are beyond forms, either those which are 'higher' (such as the supreme One), or 'lower' than forms (such as matter) (Ioanne Petritsi, Opera, v. II, p. 58-59, ch. 20). Therefore, only the transcendent One causes even matter which has neither a form nor qualities, and which we call a "non-being" because of its lack of forms, and not because of their abundance (Ioanne Petritsi, Opera, v. II, p. 43 , ch. 11). In a certain sense, the supreme One and prime matter are similar to each other: the One is imperceptible and matter is imperceptible, too. Matter is formless and the One is superior to all forms, which means that it is formless too (Ioanne Petritsi, Opera, v. II, p. 42-43, ch. 11). Thus, the One reaches even matter, which has no figure ( $\mu \circ \rho \varphi \eta$ : Petritsi uses the Greek word in Georgian transliteration; Ioanne Petritsi, Opera, v. II, p. 69, ch. 25). Therefore, it reaches even $\sigma \tau \dot{z} p \eta \sigma \varsigma \varsigma$ (privation) of forms, which is characteristic of matter (Ioanne Petritsi, Opera, v. II, p. 124-125, ch. 57). Neither the One nor matter is composite (Ioanne Petritsi, Opera, v. II, p. 126, ch. 59). Matter, as far as it has no form and figure, is one. That is one more reason why it is similar to the supreme One as its cause. Consequently, even matter desires and loves the One, because love does not exist without similarity (Ioanne Petritsi, Opera, v. II, p. 83, ch. 32; II, p. 76, ch. 28). Alexidze 2017a, p. 124.

8o Ioanne Petritsi, Opera, v. II, p. 125, ch. 57.

81 Petritsi claims that according to Platonic philosophers, there is one supreme cause of everything, and not two causes, as the Manichaens believed, and this one cause is good. The darkness has no base, and there is no substantial evil (Ioanne Petritsi, Opera, v. II, p. 213-215, epilogue).

82 Ioanne Petritsi, Opera, v. II, p. 83, ch. 32.

83 Ioanne Petritsi, Opera, v. II, p. 126, ch. 59. Moreover, as Petritsi says, the One transcends even oneness (unity) (Ioanne Petritsi, Opera, v. II p. 123, ch. 56). 
body, also a substrate, ${ }^{84}$ and it is called $i \pi \dot{\beta} \beta \alpha \theta \rho o \nu^{85}$ and $\pi \nu \theta \mu \eta \dot{\nu}{ }^{86}$ It has no activity, and it is unable to produce anything by itself. ${ }^{87}$ This is one more reason why matter, though it is unlike the supreme One, is, in a certain sense, like it: matter cannot produce anything and has no activity, while the One, though it is the supreme cause of everything, as we have said, transcends even creativity, and is superior to any kind of activity, potency or substance. According to Petritsi, incorporeal beings do not require matter, while corporeal ones need it, like accidental characteristics which need a substrate. ${ }^{88}$

The question of the relationship between the first Infinity of the Proclean ontological pair, first Limit / first Infinity, on the one hand, and matter on the other, is in my opinion one of the problems of Petritsi's Commentary. ${ }^{89}$ Petritsi claims that matter depends, in a certain sense, on the first Infinity, because it is infinite (limitless) too, is constantly changing and formless. ${ }^{90}$ But how exactly can we understand the dependence of matter on the supreme One on the one hand, and on the first Infinity on the other? In other words, in what sense are these two principles causes of matter? I suppose that if we take Aristotle's

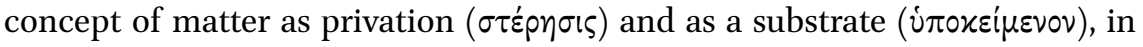
combination with Proclus' understanding of matter as non-being and his concept of the first Infinity, then we may say that in Petritsi's opinion, matter, as $\sigma \tau \varepsilon \dot{p} \eta \sigma \iota \zeta$, depends on the supreme One, while as a substrate, it depends on the first Infinity. ${ }^{91}$

Besides prime matter and matter-in-forms, Petritsi mentions celestial matter too, which is, as he says, the image and likeness $(\ddot{\alpha} \gamma \alpha \lambda \mu \alpha)$ of the intellectual heaven. This matter is governed by the highest power, Zeus. In my view, this is an indication that celestial matter and prime matter have different causes: as far as Zeus corresponds more to the demiurge and to the Intellect than to the supreme One, we can suppose, taking into consideration Petritsi's com-

84 Ioanne Petritsi, Opera, v. II, p. 100, ch. 41.

85 That means, 'base'. Petritsi uses the Greek word in Georgian transliteration (Ioanne Petritsi, Opera, v. II, p. 126, ch. 59). For the same word in relation to matter see Plot. Enn. VI 3, 4, 3-4.

86 'Foundation', 'base'. Petritsi uses again a Greek word in Georgian transliteration. Ioanne Petritsi, Opera, v. II, p. 126, ch. 59. Alexidze 2017a, p. 126.

87 Ioanne Petritsi, Opera, v. II, p. 69, ch. 25.

88 Ioanne Petritsi, Opera, v. II, p. 99-100, ch. 41.

89 The Proclean pair 'first Limit and first Infinity' is quite extensively discussed by Petritsi in his Commentary, chapters 10, 21, 40, 89-95, 159.

90 Ioanne Petritsi, Opera, v. II, p. 144-145, ch. 94-95.

91 According to Aristotle, we distinguish matter and privation; matter is in a sense substrate, while the privation in no sense is (Aristotle, Physics, I, 9, 192a3-6; 26-33). Alexidze 2017a, p. 126-127. See also O'Brien 1996, p. 178-181. 
ments on prime matter, celestial matter and their causes, that celestial matter depends on Zeus as demiurge, while prime matter depends only and directly on the supreme One. Further, Petritsi explains that celestial matter shares the destiny of immortal beings and receives intellectual forms from the hypersubstantial Logos. ${ }^{92}$ Thus, he distinguishes celestial matter from any other, lower levels of matter, including prime matter. ${ }^{93}$

Therefore, in Petritsi's opinion, the power of the supreme One reaches prime matter. But what does it mean? Is it the power of the ineffable One or is it the power of that aspect of the supreme One which is 'turned' toward production? ${ }^{94}$ I have no definite answer to this question. However, I think there is no other relation between the supreme One and prime matter apart from the fact that both of them are one, although in radically different ways. ${ }^{95}$ As Petritsi says, "nothing can escape the chains of oneness, including the non-being of matter. Although matter has no figure, it is held in the limits of oneness". ${ }^{96}$

For Petritsi, the demiurge of Plato's Timaeus is the Intellect, as it was for Proclus. Therefore, it is logical that the demiurge is not the creator of matter, because, as we have said, according to Proclus and Petritsi, the power of the Intellect reaches only those beings that have form, and cannot reach an absolutely formless matter. ${ }^{97}$ Thus, the power of the Intellect can reach only those beings that have form, but it cannot go further, either ascending 'higher' than the realm of forms, or descending 'below' their realm. ${ }^{98}$ Consequently,

92 Ioanne Petritsi, Opera, v. II, p. 73, ch. 27.

93 On celestial matter see Ioanne Petritsi, Opera, v. II, p. 73, ch. 27; II, p. 98, ch. 41; II, p. 112, ch. $5^{1 .}$

94 It seems that Petritsi distinguishes two aspects of the supreme One, though very vaguely: one of them is absolutely transcendent, while another one (preceding the Henads) is more 'turned' toward effects and is, in a certain sense, productive. See Ioanne Petritsi, Opera, v. II, p. 123, ch. 56 ; II, p. 158, ch. 116; II, p. 170, ch. 139. We shall discuss this issue in the next section of this paper.

95 As Petritsi explains, for the One, to be in everything, including formless matter, does not mean that it is really in them, but means that it is the transcendent cause and producer of everything (Ioanne Petritsi, Opera, v. II, p. 95, ch. 40).

$96 \quad$ Ioanne Petritsi, Opera, v. II, p. 124, ch. 57.

97 Ioanne Petritsi, Opera, v. II, p. 43, ch. 11. For Petritsi, as it was for Proclus, the activity of the Intellect, its 'process' of cognition, is the non-temporal process of creation (Ioanne Petritsi, Opera, v. II, p. 188, ch. 174).

98 Ioanne Petritsi, Opera, v. II, p. 189, ch. 174. Petritsi's sources for his theory of matter was, among many others, Proclus' Elements of Theology, prop. 57: according to Proclus, matter itself is not a cause of privation but rather the first Goodness: "For even privation of Form is from the Good, since it is the source of all things; but Intelligence, being Form, cannot give rise to privation" (Proclus, The Elements of Theology, prop. 57, p. 56-57,). Another source could be Proclus' commentary on Timaeus. According to Proclus, matter is pro- 
the demiurge, as Intellect, cannot be the cause or creator of prime matter. He is, if we may say so, rather a kind of a 'fashioner' of the celestial matter which he already possesses as a substrate for executing his activity. ${ }^{99}$ However, in the next section of this paper we shall see that in some cases Petritsi tries to identify the supreme One with the creator / demiurge of the physical cosmos.

As for matter itself, it does not produce anything. ${ }^{100}$ As a non-productive and infertile substrate, matter is unlike the supreme active cause. ${ }^{101}$ Therefore, we can assume again that matter depends only on the supreme One which is above every kind of creation and production, and not on the creator / demiurge. ${ }^{102}$

The relation between prime matter as the formless non-being, on the one hand, and things, which are 'material', on the other, is quite "difficult to understand". What is decisive (in other words, what is the cause) in the fact / act of 'transition' ('ascending') from the condition of 'pure' matter (absolute nonbeing) to the level of matter-in-form (corporeal being) and vice versa: in 'descending' from the level of matter-in-form to 'pure' matter? Is it the positive activity of the creative (effective) cause, or the negative passivity of the Intellect (the condition of the maximal privation of forms)? I have no definite answer to this question. However, it is evident that the dialectic of activity and potency

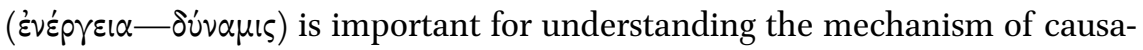
tion in the hierarchy of beings.

Thus, matter is for Petritsi a 'non-being', it is 'nothing.'103 As the supreme One is, according to Petritsi, not Being but superior to Being, and is "equally distanced", as he says, from Being as well as from non-being, that is why, in

duced from the source which precedes the Intellect, and matter is the last level of the first Infinity. The first Infinity, as well as the first Limit, is directly produced by God (the One). Consequently, matter depends on God (the One) (Proclus, In Platonis Timaeum I, p. 384385 Diehl). The demiurge, though he is not the creator of matter, is still its cause, as far as it contains unity (Proclus, In Platonis Timaeum I, p. 386 Diehl).

99 On the demiurge see Ioanne Petritsi, Opera, v. II, chapters 8, 25 and 39. However, in certain cases (but not always, as for example, in ch. 39) Petritsi, as we mentioned, seems to 'elevate' the functions of Plato's demiurge to the level of the supreme One.

100 Ioanne Petritsi, Opera, v. II, p. 68-69, ch. 25.

101 Cf. Ioanne Petritsi, Opera, v. II, p. ch. 21.

102 Petritsi explains how the demiurge makes mixtures of the four elements (Ioanne Petritsi, Opera, v. II, p. 93, ch. 39). I think, again, that we can say that the demiurge executes his activity on celestial matter, but does not reach prime matter, which is non-existent. Moreover, we can call the One the 'paternal cause', while the demiurge is rather the 'creative cause'. As Petritsi explains, the paternal cause is better and more complete than the creative cause. It spreads its activity up to the non-existent realm, while the creative cause can reach only those beings which have form (Ioanne Petritsi, Opera, v. II, p. 179, ch. 157).

103 As we said, Petritsi distinguishes two meanings of 'to be': one meaning includes a formal being (i.e. to be something definite, to exist as a form), the other means only simple 
Petritsi's interpretation, matter as non-being is opposed not to the supreme One but to the true Being. ${ }^{104}$ As for the One, which is, as Petritsi says, 'above' the Henads, it does not have any opposite entity. ${ }^{105}$ This is the reason, as Petritsi thinks, why even a non-being cannot be free from the bounds of the One, and is, in a certain sense, one, too. ${ }^{106}$ Nevertheless, although Petritsi regards matter as totally dependent on the One, he does not say that God is its creator. Nor does he refer — at least clearly and definitely — to the notion of creation from nothing. ${ }^{107}$

In Petritsi's theory, the universal principle of everything is the transcendent One, which is one and nothing else. It is not a composite and does not imply any kind of plurality in itself. Moreover, it is even beyond oneness. As Petritsi says, all causes give their selfhood to their effects, but the supreme One does not share its transcendent selfhood, ${ }^{108}$ and it does not get anything from the effects. ${ }^{109}$ Thus, the One keeps its identity without sharing it with others and none of the Henads, as Petritsi says, can rise up to the dignity of its absolute unity. ${ }^{110}$ According to Petritsi, the supreme One is not in its effects, because it is the transcendent cause and producer. ${ }^{111}$ In Petritsi's opinion, the supreme

existence. Correspondingly, he distinguishes also two kinds of non-beings. Interestingly, for characterizing prime matter as a non-being he uses the second meaning of this word, which is to say that matter is absolutely nothing, non-existent at all (Ioanne Petritsi, Opera, v. II, p. 58, ch. 20). That's why, if we follow Petritsi's interpretation of matter, as I think, we can say, that as a non-existant, it is opposed (and, at the same time, is like) the supreme One, while as a non-being it is opposite to the first Being / Form / Intellect.

104 Ioanne Petritsi, Opera, v. II, p. 170, ch. 139.

105 The One, as we said, transcends even unity ('onenness') and causality (Ioanne Petritsi, Opera, v. II, p. 123, ch. 56).

106 Ioanne Petritsi, Opera, v. II, p. 170-171, ch. 139.

107 Quite ambiguous is chapter 39. In this chapter Petritsi says that the One produces being from non-being (Ioanne Petritsi, Opera, v. II, p. 93, ch. 39; Alexidze 2014b, p. 236). Although it is difficult to determine whether Petritsi here means an absolute nothingness or matter as a privation of being, he certainly does not speak about the creation of matter itself. Cf. also Ioanne Petritsi, Opera, v. II, p. 25-26, ch. 3; p. 171, ch. 139; p. 179, ch. 157. Alexidze 2017a, p. 133 .

108 Ioanne Petritsi, Opera, v. II, ch. 56, p. 123 .

109 Ioanne Petritsi, Opera, v. II, ch. 1, p. 16. On Petritsi's theory of the supreme One see Alexidze 2017 b, p. 63-86.

110 Ioanne Petritsi, Opera, v. II, p. 19, ch. 2.

111 Ioanne Petritsi, Opera, v. II, p. 95, ch. 40. 
One remains eternally in its selfhood and produces the otherness of the effects, while as a producer it does not change in its selfhood. ${ }^{112}$ As the numeric one contains all kinds of plurality without any mixture or parts, in the same way the transcendent One embraces in itself all hyper-forms, forms, paradigms and images, ${ }^{113}$ containing plurality as a unity. ${ }^{114}$ As Petritsi says, only the supreme One is a real cause of the unity of the multiplicity of the series; other causes, as far as they are in some sense plural, cannot provide such unity.115

Therefore, the supreme One is, on the one hand, transcendent, but, on the other, the cause of everything. But how does Petritsi combine these two different aspects of the supreme One? In my opinion, the following characteristics of the supreme One cannot be 'removed' and negated, and they always remain as its affirmative characteristics: The supreme One is the cause of everything (and more exactly the cause of the simple existence of everything), including beings and non-beings, those that have form and also of formless matter; ${ }^{116}$ the supreme One 'sees' everything, that means, it is the principle of providence for everything; ${ }^{117}$ the supreme One is equally distanced from everything, though everything participates in it through its own one differently (though it is not

\footnotetext{
112 Ioanne Petritsi, Opera, v. II, p. 73, ch. 27.

113 Ioanne Petritsi, Opera, v. II, p. 30, ch. 6.

114 Ioanne Petritsi, Opera, v. II, p. 58, ch. 20.

115 Ioanne Petritsi, Opera, v. II, p. 65, ch. 23.

116 The supreme One is transcendent and is equally cause of everything: of the first beings and of those which come thereafter, of the universals, of the partials, of the non-mortals and of the mortals (Ioanne Petritsi, Opera, v. II, p. 59, ch. 21).

117 As Petritsi says, harmony was established among beings, in order to provide their relationship with each other, and the providence of the all-seer descends and embraces everything down to the last ones (Ioanne Petritsi, Opera, v. II, p. 152, ch. 106). Providence comes from the supreme One and rules over everything, and fate, which governs nature, is subordinated to providence. The activity of providence is spread over all kinds of beings, though on the lower levels its presence is not very clear to us. Nothing remains outside of the providential power: even human thoughts cannot hide from the divine providential knowledge. The will of the supreme One rules over everything including matter (Ioanne Petritsi, Opera, v. II, p. 82, ch. 31; II, p. 196, ch. 190; II, p. 212, epilogue). The principles of the order produced together with beings are above beings and we call them "providence". As Petritsi says, the principles of providence are in the ineffable One, and it provides beings with their own order. There is one cause for all beings, and nothing can escape its order and providence (Ioanne Petritsi, Opera, v. II, p. 39-41, ch. 11). According to Petritsi, every being, such as intellect, soul, nature, heaven received its own place in the universe; this was established by the creative universal order, and nothing can contradict it (saying this, Petritsi makes reference to Timaeus; Ioanne Petritsi, Opera, v. II, p. 86, ch. 34; II, p. 98, ch. 41). Alexidze 2017b, p. 69-78.
} 
the supreme One that is the cause of the differences of the effects); the supreme One is the source of the reversion of everything to its cause and indirectly to it (the supreme One) as to the primal cause of everything.

Thus, these affirmative definitions, though they characterize the supreme One in its relation to the effects, and express its productive ability, do not depend strictly on the effects, although of course in a certain sense they do. I think we can say that those affirmative characteristics which express the productivity of the supreme One, its providential activity and its power of providing the reversion of the effects back to their causes, are certain kinds of 'absolute' characteristics of the One as the supreme cause of everything. They are not attributes; paradoxically, they do not depend on the effects produced by the supreme One or on our way of its "understanding it": they would still remain as characteristics or, more exactly, as the absolute, unchangeable expression of the hypersubstance of the transcendent One, even if its effects had not existed (which is in principle impossible) or if we have not made an attempt to interpret it.

However, it seems that Petritsi feels slightly uneasy with this contradiction between the transcendence of the supreme principle, on the one hand, and its creativity, causality and providential power on the other. Nevertheless, he does not criticize Proclus for that contradiction, as Damascius did. ${ }^{118}$ Proclus is the greatest philosopher for Petritsi, and he never criticizes him. But he had to do something in order to make the contradiction smoother. He needs to explain the transition from the transcendence of the One to the same One as a principle of the production of the effects. That is why, as I think, he introduces (or attempts to introduce, because he does it very vaguely) another One between the supreme transcendent One and the composite One (true Being). However, Petritsi seems not to be entirely sure of the 'existence' of this kind of the One. He does not write about it definitely and clearly, but we find an indication that he needed it for a coherent interpretation of Proclus' philosophy. Such a 'second' One was postulated by Iamblichus ${ }^{119}$ (that was a reason why Damascius liked him and criticized Proclus). ${ }^{120}$ Petritsi, it seems, tries to reconcile the position of Iamblichus with that of Proclus. However, he does not criticize Proclus

118 Simplicius, In Aristotelis Physicorum, p. 795.11-17: "As far as Damascius is concerned, by his commitment to his work, and because of his sympathy towards the ideas of Iamblichus, he did not hesitate to contradict Proclus' doctrines on many occasions." In van Riel 2010, p. 676 .

119 Damascius, Traité des premiers principes, I, 101-103, p. 25-28. Dillon 2010, p. 36o.

120 van Riel 2010, p. 676. 
as Damascius did. Petritsi does not mention Damascius at all, and he does not mention Iamblichus either while discussing this subject, though he mentions him in other cases.

Thus it appears that Petritsi, while looking for the object (or the subject) of the affirmative characteristics, comes to the conclusion that it cannot be the supreme One because of its absolute transcendence. Therefore, he very cautiously introduces another One, which is before the Henads. Can we call it a 'hypostasis' in the same way that the Intellect and the Soul are hypostases? I do not think so. It looks more like the 'mode' or the 'aspect' of the supreme One, in the sense that, like the first effect of its own activity, it is inseparable (or almost inseparable) from its hypersubstance.

Here is a vague indication that there is one more One after the supreme One and before the Henads: in the commentary on prop. 116, misinterpreting (as I think) this proposition of Proclus, Petritsi wrote that the first One is above participation, but the second and the originated One is the cause of participation for all participants. Thus, the causes of the Henads are different: the first One is the cause of the Henads in such a way that it does not give its selfhood to those Ones which are after it; but the One originated by the supreme One is the cause that gives its selfhood to the series of the Henads. According to Petritsi, there is also another One which is composite (Petritsi means true Being) and is after the Henads. ${ }^{121}$ A similar case is in the commentary on prop. 56: again, Petritsi misinterprets Proclus' text and his own translation. While Petritsi's translation of this proposition is correct, his commentary is different and does not correspond either to Proclus' text or to his own translation. It seems that according to Petritsi's commentary on prop. 56 , there is one more 'One' above the first One which is the most perfect image of the supreme One and more similar to it than anything else. Thus, the supreme One is the cause of all causes as well as of all effects. ${ }^{122}$

There are also other cases in Petritsi's Commentary, where, as I think, he tries to say that there is one more One after the supreme One and before the Henads, even before the first Limit and the first Infinity. Interestingly, he does not express this idea elsewhere (except in the above-mentioned commentaries on prop. 56 and 116), but we can come to this conclusion if we take into consideration the context of his commentary, in which the supreme One, the demiurge, the Logos, the intelligible paradigm and the material cosmos are related to each other. Thus, in the commentary on prop. 29, Petristi, making reference

121 Ioanne Petritsi, Opera, v. II, p. 158, ch. 116.

122 Ioanne Petritsi, Opera, v. II, p. 123, ch. 56. Alexidze 2017b, p. 79-81. 
to "his Paul", says that the Logos/Son is image, likeness and $\dot{\varkappa} \mu \alpha \gamma \varepsilon \hat{\varepsilon} 0 v$ of the supreme One, also called "Father"; the Logos/Son is "the unchangeable image of the One" (meaning, of the Father). The Logos is boundless and it precedes beings and the Henads, and is the form of forms (ch. 29, p. 78). ${ }^{123}$ "The infinite and most intensive likeness" of the Logos/Son with the Father, the fact that "it carries in itself the whole richness of the Father" means that Petritsi interpreted the relation between God and Logos in an orthodox Christian way. I think Petritsi felt a certain identity or similarity (or he looked for this identity or similarity) between Christian Logos/Son and that aspect of the supreme (Proclean) One which represents it as the cause, creative and providential principle of everything. Petritsi needed the 'second One' he mentioned in the commentary on prop. 116 for the same purpose he 'needed' the Logos/Son while interpreting Proclus' philosophy: both of them, the 'second One', on the one hand, and the Logos/Son, on the other, were, in Petritsi's opinion, as I think, mediators between the supreme One as the transcendent principle and the same supreme One as the cause of everything. Thus, the analogy between the Logos and the 'second' One gets its sense if we take into consideration the main affirmative characteristic of the supreme One: the fact that it is the cause of everything.

Moreover, not only the analogy between the 'second One' and the Logos served Petritsi for expressing the universal causality of the supreme One, but the analogy between the supreme One and Plato's demiurge as well. Interestingly, in Petritsi's interpretation, in certain fragments of his Commentary, the supreme One, as the cause of the intelligible as well as of the visible cosmos, acquires the characteristics of the demiurge of Plato's Timaeus. By means of such identifications (or analogies), the supreme One acquires features of a personal God. Petritsi discusses the providential power of the first principle, its ability to 'see' everything and says that it transposes its selfhood into the multiplicity of powers (potencies) and produces that which comes after it. Petritsi claims that the One knows neither lack of power (potency) nor envy (here Petritsi mentions Plato's Timaeus), is hyper-complete and can produce complete effects, and that providence comes from the supreme principle. ${ }^{124}$ But what causes the all-seer, who is above every kind of natural necessity ( $\alpha \dot{\alpha} \gamma \gamma \eta \eta)$, to produce beings? Petritsi makes reference to Timaeus and responds that the cause and the mediator between the producer and the effects is good-

123 Cf. Ioanne Petritsi, Opera, v. II, epilogue: here Petritsi argued that the One corresponds

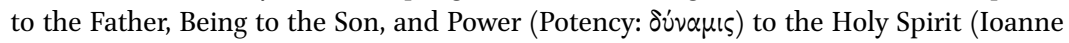
Petritsi, Opera, v. II, p. 210, epilogue; Alexidze 2014b, p. 235).

124 Ioanne Petritsi, Opera, v. II, p. 32, ch. 7 . 
ness, and that the hyper-complete principle proceeds in order to let others participate in its goodness, because goodness is free from envy and lacks no power. ${ }^{125}$

Thus, in Petritsi's understanding, the supreme One, in spite of its transcendence, has certain positive characteristics, inseparable from its transcendent selfhood. These are its causality, productivity, and providential power. It seems that even in the case of their negation, i.e. even if we say that it is above all this, or even if we try to 'forget' the effects, we cannot totally separate these characteristics from the 'nature' of the supreme One. As they represent its hyper-substance, they are not its attributes but 'belong' in a certain sense to its selfhood. However, I think that Petritsi did not feel very comfortable with the idea that the supreme One is, on the one hand, absolutely transcendent and, on the other, the cause and producer of everything. In order to make the transition from the first aspect of the supreme One (its transcendence) to another one (its productivity) more coherent, Petritsi made a timid attempt to introduce in his Commentary the 'second' One. I think it is not another 'hypostasis' but rather another aspect or mode of the supreme One. The second One is almost inseparable from the supreme One but is more 'turned' to the effects than the transcendent One. This 'second' One must be regarded as a certain mediator between the transcendence of the supreme One and its creative power. In my opinion Petritsi identified the creative aspect of the One with the Logos/Son and also with Plato's demiurge for the same purpose. ${ }^{126}$

\section{5} Conclusion

The cause and effect relationship is one of the major themes of Ioanne Petritsi's Commentary on Proclus' Elements of Theology. It is important for Petritsi on all levels of the ontological hierarchy, starting with the supreme One and ending with formless matter. Petritsi shares the main principles of Proclus' philosophy, according to which a cause is more than the effect, and the 'higher' a cause is, the further its power is extended. The supreme One, though it is transcendent, is, at the same time, the cause of everything, and its power (though it is supe-

\footnotetext{
125 Ioanne Petritsi, Opera, v. II, p. 68, ch. 25. See also Ioanne Petritsi, Opera, v. II, p. 210, epiloge: "The Attican says about the production of the beings, that the goodness of God could not remain in itself, and came down, in order to make the others also participants of its goodness, because the goodness is free from envy".

126 Alexidze 2017b, p. 82-86.
} 
rior to any kind of power, activity or substance) extends to prime matter. In order to 'reconcile' the transcendent aspect of the supreme One with its universal power of causation, Petritsi, as I think, made an attempt to 'introduce' yet another one after the supreme One and before the Henads. This is a kind of 'second aspect' of the supreme One, almost inseparable from it, which provides the transition from its transcendent hyper-substance toward its productive and causal activity.

\section{Acknowledgements}

I am very grateful to Dragos Calma, the anonymous reviewer and Liz Curry for their remarks on this paper.

\section{Bibliography}

\section{Primary Sources}

Damascius, Traité des premiers principes, Volume II. De la triade et de l'unifié. Texte établi par L.G. Westerink traduit par J. Combès, Paris, Les Belles Lettres, v. I-1986, v. II-1989, v. III-1991.

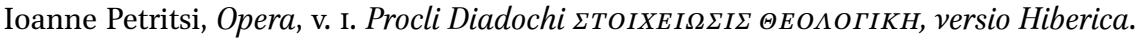
Textum Hibericum edidit commentariisque instruxit S. Kauchtschischvili. Tbilisi, Sumptibus Universitatis Tbilisiensis, 1940 (in Georgian).

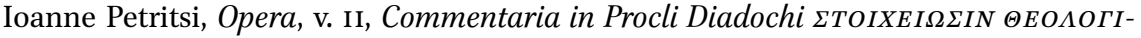
$K H N$. Textum Hibericum ediderunt commentariisque instruxerunt $S$. Nutsubidse et S. Kauchtschischvili, Tbilisi, Sumptibus Universitatis Tbilisiensis, 1937 (in Georgian). Ioane Petrizi, Kommentar zur Elementatio theologica des Proklos. Übersetzung aus dem Altgeorgischen, Anmerkungen, Indices und Einleitung. Herausgegeben von L. Alexidze und L. Bergemann. Amsterdam/Philadelphia, B. Grüner, 2009.

Proclus, The Elements of Theology. A revised text with translation, introduction and commentary by E.R. Dodds. 2nd ed. Oxford, Clarendon Press, 1963.

Proclus, In Platonis Timaeum, ed. E. Diehl, Leipzig, Teubner, v. I-1903, v. II-1904, v. III1906.

Proclus, Théologie platonicienne. Texte établi et traduit par H.D. Saffrey et L.G. Westerink, Paris, Les Belles Lettres, v. I-1968, v. II-1974, v. III-1978, v. IV-1981, v. V-1987, v. VI-1997. 


\section{Secondary Literature}

Alexidze, L. (2002), "Zum Verhältnis zwischen Neuplatonischem und Christlichem im Prokloskommentar des Ioane Petrizi", in Th. Kobusch, M. Erler (eds), Metaphysik und Religion. Zur Signatur des spätantiken Denkens (Akten des Internationalen Kongresses vom 13.-17. März in Würzburg), München, Leipzig, K.G. Saur, p. 429-452.

Alexidze, L. (2014a), “'One in the Being' and 'One within Us': The Basis of the Union with the One in Ioane Petritsi's Interpretation of Proclus' Elements of Theology”, in T. Nutsubidze, C.B. Horn, B. Lourié (eds), Georgian Christian Thought and Its Cultural Context. Memorial Volume for the 125th Anniversary of Shalva Nutsubidze. Leiden/Boston, Brill, p. 175-193.

Alexidze, L. (2014b), "Ioane Petritsi”, in S. Gersh (ed.), Interpreting Proclus. From Antiquity to the Renaissance. Cambridge, Cambridge University Press, p. 229-244.

Alexidze, L. (2017a), "Matter in Ioane Petritsi's Commentary on Proclus'Elements of Theology", in A. Le Molli, L. Alexidze (eds), Prote Hyle. Notions of Matter in the Platonic and Aristotelian Tradition. Palermo, Palermo University Press, p. 123-134.

Alexidze, L. (2017b), "The Supreme One: Its Transcendence and Its 'Kataphatic' Characteristics in Ioane Petritsi's Philosophy”, in M. Baumbach, O. Pluta (eds), Bochumer philosophisches Jahrbuch für Antike und Mittelalter, 20, Amsterdam/Philadelphia, John Benjamins Publishing Company, p. 63-86

O’Brien, D. (1996), "Plotinus on Matter and Evil”, in L.P. Gerson (ed.), The Cambridge Companion to Plotinus, Cambridge, Cambridge University Press, p. 171-195.

Dillon, J. (2010), "Jamblichus", in L.P. Gerson (ed.), The Cambridge History of Philosophy in Late Antiquity, Volume I, Cambridge, Cambridge University Press, p. 358-374.

Gigineishvili, L. (2007), The Platonic Theology of Ioane Petritsi. Piscataway, NJ, Gorgias Press.

van Riel, G. (2010), "Damascius", in L.P. Gerson (ed.), The Cambridge History of Philosophy in Late Antiquity, Volume II, Cambridge, Cambridge University Press, p. 667696. 